\title{
PERAN PEMERINTAH PEMKOT MAKASSAR DALAM MEMBANGUN BUDAYA RELIGIUS SEBAGAI PEMBENTUK KARAKTER SPRITUAL
}

\author{
Laode Muhamad Fathun \\ UPN Veteran Jakarta, Email : 1m_fathun@yahoo.co.id
}

\begin{abstract}
ABSTRAK
Paper ini bertujuan menjelaskan bagaimana strategi Pemerintah Kota Makassar dalam menjadikan nila-nilai Islamiah dalam membentuk ukhuwah di Makassar. Dengan menggunakan konsep analisasi teori Buyda dan teori Kepemimpinan menjadi pisau analisis penulis menganalisa strategi Pemerintah membentuk ukhuwah Islamiah di Makassar. Sederhananya bagaimana intervensi politik terhadap fenomena keIslaman. Dengan tipe penulisan deskriptif analitik serta teknik pengumpulan data sekunder dan primer diperoleh hasil bahwa Pemerintah Kota Makassar menggunakan nilai-nilai keIslaman yakni sholat subuh dengan segala faedahnya sebagai strategi memupuk tali silaturahim sekaligus membangun nilai moralitas ukhuwah di Makassar. Dengan dihadiri ribuan warga dari pejabat pemda, swasta, pelajar dan mahasiswa serta masyarakat lainya menjadi bukti keseriusan pemerintah menjadikan sholat subuh berjamaah sebagai instrument membangun ukhuwah Makassar yang religius. Dalam konteks inilah apabila control politik terhadap agama dilakukan dengan baik oleh pemimpin yang transformatif maka tidak ada keterpisahan natara Islam dan politik, karena Islam adalah tuntunan politik, sosial, ekonomi, dan hukum yang sempurna dalam masyarakat.
\end{abstract}

Kata-Kata Kunci : Pemkot Makassar, Nilai Islamiah, Ukhuwah, Moralitas, Religius, transformatif

\begin{abstract}
This paper aims to explain how the strategy of the Government of Makassar in making the values of Islamiah in shaping ukhuwah in Makassar. By using the concept analisasi Buyda theory and the theory of leadership into a blade analysis the authors analyze the Government's strategy to form the Islamic brotherhood in Makassar. Simply how political intervention against Islamic phenomenon. With this type of analytic and descriptive writing techniques of secondary and primary data collection showed that the Government of Makassar using Islamic values that the dawn prayer with all its usefulness as a strategy to cultivate friendship rope while building morality ukhuwah in Makassar. Attended by thousands of local officials, private, school and university students as well as other public evidence of the seriousness of the government to make the dawn prayer in congregation as an instrument to build Makassar religious brotherhood. In this context when political control of religion done by leaders who transformative natara then there is no separation of Islam and politics, because the guidance of Islam is political, social, economic, and perfect law in society.
\end{abstract}

Keywords: Government of Makassar, Islamic value,Ukhuwah, Morality, Religion, Transformative Top of Form. 


\section{Islãmadîna \\ JURNAL PEMIKIRAN ISLAM}

\section{PENDAHULUAN}

Indonesia merupakan Negara yang di sinyalir sebagai pemeluk Islam terbesar di dunia. Dengan kompoisisi bisa mencapai 80 persen jumlah penganut Islam menunjukan bahwa Islam berkembang dengan pesat di Indonesia. Islam di Indonesia bukan hanya menjadi sekedar agama namun menjadi tuntunan dalam berbagai sendi kehidupan baik sosial, budaya, politik dan ekonomi. Pengaruh Islam di Indonesia terlihat jelas seperti dalam bidang ekonomi munculnya perbankan syariah, dalam bidang sosial santunan sedekah, dalam bidang hukum seperti madrasah serta yang tidak kalah menarik adalah pengaruh Islam dalam politik yakni munculnya partai-partai politik berbasis Islam sampai peraturan dan kebijakan didaerah terkait dengan Islam.

Realitas tersebut menjadi bukti bahwa Islam sudah menjadi ideologi di Indonesia yang merambah keseluruh sendi-sendi kehidpan masyarakaat Indonesia. Di sinilah perlu di redefinisi pula bahwa Islam itu bukan sekedar agama yang mengatur hubungan vertikal namun juga sangat kuat mengatur hubungan horizontal kepada sesama manusia. Sehingga, munculah tesis bahwa "Islam Solution in the life". Dengan demikian Islam hadir sebagai fondasi dalam mengarungi kehidupan secara vertical yakni manusia dengan penciptanya serta horizontal yakni manusia dengan sesama manusia. Terutama dalam Islam berlaku kuat tradisi " sebaik-baik orang dialah yang bermanfaat bagi orang lain". Oleh sebab itu bukan hal yang tabu apabila nila-nilai islami menjadi ilham dan nur yang melekat dalam individu penganutnya.

Salah satu bagian dari Indonesia adalah Kota Makassar yang sebagian besar dan mayoritas pendudukanya adalah Islam. Makassar menjadi salah satu bukti sejarah proses menyebarnya Islam di nusantara. Makassar menjadi salah satu kota penting dalam sejarah nasional. Bahkan sejak tahun 1500an Makassar menjadi salah satu kota dagang di nusantara yang juga menjadi basis perdagangan lokal kala itu bahkan perdagngan internasional. Makassar menjadi kota pelabuhan tempat singgah sudagar-sudagar dari berbagai belahan dunia dari Arab, China hingga Eropa. Salah satu dampaknya adalah menyebarnya Islam di Makassar yang di berbagai sumber di tuliskan dari para saudagar-saudagar itu.

Ketika saat itu nusantara masih berbasis kepercayaan animisme dan agama hindu serta budha, agama Islam yang dibwa oleh para saudagar-saudagar justru menjadi daya tarik yang memikat bagi masyarakat loka untuk beinterkasi. Dengan tata cara yang moralis, transaksi perdagngan yang jujur, menjadi isntrumen yang kuat untuk menjalin hubungan antar manusia saat itu. Dari perjalanan suadagar-suadagar itulah proses penyebaran Islam yang di tuliskan dalam berbagai literatur dari tanah Sumatra oleh Datok Ditiro dan kemudian singgah di Kabupaten Bulukumba melalui Datok Ribandang sampai menyebar keseluruh penjuru nusantara.Proses perjalanan masuknya Islam di Indonesia memiliki historis yang panjang akibatnya tidak heran kalau penganut Islam di Indonesia sangat banyak padahal sebelumnya telah di dominasi oleh ajaran 
animism.

Berkaitan dengan kronologi di atas, Makassar sebagai Kota Dagang membawa perbuhan besar dalam perkembangan sosial, politik dan hukum di Makassar. Setelah kilas balik sejarah tersebut menjadikan Makassar sebagai salah satu Kota Religious yang terkenal di nusantara. Realitas ini terbukti dengan masih adanya peninggalan-peninggalan sejarah Datuk Ditiro dan Ribandang di Makassar selain itu juga peninggalan Syekh Yusuf yang merupakan tokoh besar di Makassar kala itu yang bahkan menyebarkan Islam sampai ke Afrika. Dalam konteks Kota religious inilah, terpilihnya Dani Pomanto sebagai Walikota baru di Makassar ingin mengembalikan Kota Makassar sebagai Kota religious dengan kepemimpinan religious. Dalam arti pemimpin yang baik adalah pemimpin yang memberi teladan bagi masyarakatnya. Kondisi tersebut menjadi tuntutan spiritual bagi Dani Pumando untuk merumuskan kebijakan ideologis, bahwa nilai-nilai keIslaman harus menjadi bagian dari pembangunan social, budaya, hukum dan politik di Makassar. Tujuanya adalah sudah pasti untuk memupuk keakraban bukan hanya dengan sesama penganut Islam namun dengan agama lainya. Faktualnya adalah agama bukan sekedar tuntutan spiritual tetapi nilai moralitas agama mengajarkan untuk berbuat baik kepada siapapun.

Dengan demikian tulisan ini akan membahas fenomena tersebut dimana berangkat dari pertanyaan bagaimana strategi pemerintah Kota Makassar dalam memupuk religiousitas di Makassar untuk membangun ukhuwah Islamiah dimakassar. Sebab dengan kepemimpinan religious cenderung akan menciptakan msyarakat yang religius pula. Artinya pemimpin sebagai teladan harus menjadi contoh yang baik bagi warganya sesuai dengan tuntunan hadist dan alquran dalam surah Annisa (Ulil Amri) karena setiap manusia akan dimintai pertanggung jawannya. Oleh sebab itu, pemimpin yang religious adalah menjadi contoh bukti bahwa antara Islam dan politik tidak harus terpisahkan tetapi saling melengkapi.

\section{TELAAH PUSTAKA}

Kepimpinan yang baik merupakan syarat suatu wilayah baik daerah atau Negara dalam upaya mensejaterakan rakyatanya. Pemimpin yang ideal itu harus memenuhi kaidah -kaidah yakni pemimpin harus adil, jujur, berintegritas, berkapabilitas dan yang paling penting adalah harus berlandaskan setiap keputusannya dengan basis ideologis nilai moralitas dan agama. Hal ini di dasarkan bahwa agama harus menjadi fondasi dasar dalam proses pengambilan keputusan yang tentunya dalam tuntunan konstitusi dan tidak melanggar akidah. Dalam konteks Islam sebagai agama yang membawa pencerahan tentunya proses pemilihan pemimpin harus melalui tahap-tahap yang sesuai dengan tuntan Al Quran dan Hadist serta Fatwa para ulama. Fakta inilah menunjukan bahwa antara Islam dan politik tidak harus terpisah. Bisa di asumsikan bahwa politik terkait dengan nilai (value), kepentingan ( interest) dan kekuasaan (power). Sedangkan Islam terkait dengan hukum standar prilaku. Dalam arti 


\section{Islãmadîna \\ JURNAL PEMIKIRAN ISLAM}

hukum ini harus menjadi patokan dalam merumuskan putusan.

Kolaborasi inilah yang menunjukan bahwa politik adalah implementasi atau apa adanya, sedangkan Islam mengenai apa yang seharusnya atau idealitas yakni berupa standar hukum dan moralitas. Kolaborasi politik dan Islam tertuang dalam asumsi nilai yakni berhubungan dengan sesuatu yang dianggap baik dan patut diperjuangkan. Nilai itu menjadi tujuan yang mendasari tindakan. Hubungan nilai -nilai tersebut dalam kerangka sistimatis itulah disebut dengan ideologi. Dilain sisi, kepentingan adalah sebuah entitas yang membuat nilai itu memperoleh dinamika. Dimana kepentingan menjadi goal untuk melakukan keputusan. Artinya goal tersebut berhubungan dengan bagiamana menunjukan pengaruh dan kontrol. Sedangkan kekuasaan merupakan implemntasi terhadap nilai tersebut dalam proses ditsribus dan akumulasi agar nilai-nilai ideologis tersebut bisa dinikmati. Disinilah, keterkaitan fondasionalisme Islam terhadap kontrol politik. Seperti yang telah dijelaskan di atas bahwa Islam terkait dengan cita-cita, hukum dan standar moralitas, maka nilai yang dimaksudkan secara politik di atas adalah ideologi Islam sebagai pijakan. Pijakan yang dimaksud adalah syariat Al quran, hadis dan ijma ulama. Islam menyebutnya Quran dan Hadist sebagai Undang-undang atau yang dalam Islam dikenal dengan istilah Siyasah dan syariah. Siyasah merupakan sebuah tindakan yang mendatangkan kebaikan, Sedangkan Syariah (hukum) artinya sesuatu ketetapan menurut syara berdasarkan kehendak Allah ( Fathun:2015). Dengan demikian bahwa konteks politik berhubungan dengan pemerintah (government), distribusi/ alokasi (distribution) dan public (masyarakat). Unsur ini menunjukan bahwa ideologi Islam sebagai hukum harus menjadi landasan teoritik dalam menciptakan budaya kepemimpinan yang religious karena budaya kepemimpinan yang religious terkait dengan nilai yang akan dinikmati oleh masyarakat dalam bentuk keputusan dan kebijakan pemerintah (Fathun:2016). Dalam lingkup bahasan makalah ini adalah mengambil konteks Kota Makassar sebagai bagian dari Indonesia dalam upaya menciptakan budaya kepemimpinan religious di Makassar melalui respon kebijakan Walikota.

Makassar sebagai bagian dari Indonesia yang sebagian besar adalah penduduknya memeluk Islam sudah menunjukan keprihatinannya terhadap buruknya implemntasi syariah terhadap politik di Indonesia. Sampai saat ini hukum yang di terapkan belum cukup mewadahi syariat Islam sebagai bagian dari budaya masyarakat dalam membentuk pola standar moralitas. Islam masih di jadikan secondary interest padahal Islam adalah mayoritas. Namun, bukan maksud penulis menyuruh untuk mengholistik kebijakan yang pure berbasis Islamis, karena Indonesia multi budaya, akan tetapi minimal budaya Islam harus bisa mengontrol dan menjadi standar kebijakan dalam membentuk prilaku. Sampai saat ini praktek tersebut belum maksimal di mainkan oleh sejumlah pemerintah daerah di Indonesia, hal ini baru terhitung beberapa tempat sebut saja Aceh, Kabupaten Bulukumba yang memang sudah menerapkan syariat Islam. 
Proses pembentukan budaya inilah yang harus dilandaskan oleh syariat Islam sehingga golanya akan menciptakan kepemimpinan yang jujur, adil amanah dan bertanggung jawab dan religious. Kalau berangkat dari definisi budaya itu sendiri, bahwa makna budaya memiliki arti yang sangat luas dan selalu mengalami perkembangan sesuai dengan tindakan dan prilaku manusia dalam ekosistemnya. Dalam definisi yang di ungkapkan oleh Tasripin Tahara yang merupakan dosen Antropoligi FISIP UNHAS mengatakan bahwa Budaya adalah ide, gagasan, nilai, norma, tindakan serta hasil karya manusia yang diperolehnya sejak lahir hingga hidup melalui proses belajar Dalam definisi ini mengisyaratkan bahwa budaya itu sesuatu yang tidak pernah terlepas dari prilaku manusia dengan alanya dalam bentuk interaksi.Budaya menyangkut dengan segala sesuatu yang dilakukan oleh manusia.

Roger M. Keesing seorang Antropolog yang meneliti definisi budaya yang sangat luas dari berbagai definisi yang telah ada dengan judul tulisan Teori-Teori Tentang Budaya mengatakan bahwa pada dasarnya manusia merupakan mahluk yang adaptif yakni mahluk hominid yang merupakan mahluk yang selalu berevelosi sesuai perkembanganya. Manusia menciptakan interaksi dalam berbagai gerak tubuhnya secara simbolik agar dia menjadi " manusia". Maksudnya adalah manusia selalu bergerak bebas dengan berbagai keanekaragaman individualitas dan menjadi sistem dalam ekosiem. Manusia selelu berupaya menuju kesempurnaan dengan seleksi biologis menurut sistem alam. Menurutnya bahwa budaya harus menuju kesempurnaanya dimana ada dua makna tentang ini (1) kalau mendefinisikan budaya adalah tradisi yang merupakan konvensi maka definisi akan menemukan primal man atau tradisi bugil manusia dan ini merupakan konvensi yang keliru apabila harus di nyatakan sebagai budaya. (2) Budaya harus memiliki arti yang kompleks dan tidak bertentangan dengan ideologis dan pengetahuan sehingga budaya menjadi kultur kebijaksanaan. Budaya adalah semua cara yang bentuk-bentuknya tidak langsung berada di bawah kontrol genetik yang bekerja untuk menyesuaikan individu-individu dan kelompok ke dalam komuniti ekologi mereka.Jadi budaya itu meyangkut proses adaptif, sistem ideasional, sistem kognitif, sistem sosioekonomi, sistem simbolik yang memang di lakukan oleh manusia. Budaya itu menyangkut segala sesuatu berupa tindakan. Budaya sebagai sebuah sistem yang kompleks ini penulis membatasinya pada budaya Islam yang religious. Tolak ukurnya religious adalah bagaimana sistem sosial, sistem pemerintahan menjadikan nilai Islam atau budaya Islam sebagai kulutural kebijakan pemerintah. Dalam koteks ini terkait dengan bagaimana kebijakan dirumuskan untuk mengakumulasi kepentingan religious suatu masyarakat tertentu. Kondisi ini tentunya berkaitan dengan pola kepemimpinan atau tata cara memimpin sebagai leader atau nahkoda dalam suatu sistem pemerintahan.

Kepemimpinan berasal dari kata pimpin. Kata pimpin dimaknai sebagai membina mengarahkan, atau menuntun, mengatur, ataupun mempengaruhi. Pemimpin yang merujuk pada aktonya memiliki tanggung jawab baik secara fisik maupun spiritual kepada hal hal yang berhubungan dengan keberhasilan 


\section{Islãmadîna \\ JURNAL PEMIKIRAN ISLAM}

aktivitas kerja dari yang dipimpinnya, oleh sebab itu, seorang pemimpin itu tidak mudah dan tidak pula sulit, akan tetapi setiap orang mempunyai kesamaan dan perbdeaan di dalam menahkodai ke-pemimpinannya. (Miftah Thoha:2010: 9) kepemimpinan adalah kegiatan untuk memengaruhi perilaku orang lain, atau seni memengaruhi perilaku manusia baik perorangan maupun kelompok. Menurut (Wahjosumidjo 2005: 17) kepemimpinan di definisikan kedalam istilah perilaku pribadi, sifat-sifat, pengaruh terhadap orang lain, hubungan kerja sama antarperan, pola- pola, interaksi kedudukan dari satu jabatan administratif, dan persuasif, dan persepsi dari lain- lain tentang legitimasi pengaruh. Kedua definisi ini menyangkut hal bahwa kepemimpinan itu merupakan proses politik yang didefinisikan oleh realism politik Morgenthau dan Wolfe bahwa kepemimpinan adalah seni mengelola power (kekuasaan/kekuatan) mengontrol orang lain dalam bentuk pengaruh ( influence, authority, dan force) untuk mengikuti tujuaan pemimpin tersebut yang terkadang ada dalam suatu tujuan yang sama namun ada juga bersebrangan.

Kepemimpinan terkait dengan proses politik dimana orang yang di anggap figur yang memiliki kelebihan dari pada orang lain atau kelompok lain yang dalam pemilihanya memlalui tahap-tahap yang telah disepakati atau konsesnsus. Kepemimpinan terkait dengan kontrol politik atau distribusi kekuasaan dari akumulasi nilai yang diharapkan bisa menjadi tujuan bersama. Dimana nilai-nilai yang dimaksudkan disini adalah nilai ideologis Islam sebagai sistem kultural, sistem sosial, sistem hukum dan sistem politik di Kota Makassar.Dalam bentuk bagan yang di kelola penulis dalam berbagai sumber sebagai berikut

\section{Skema 1: Model Teori Memimpin}

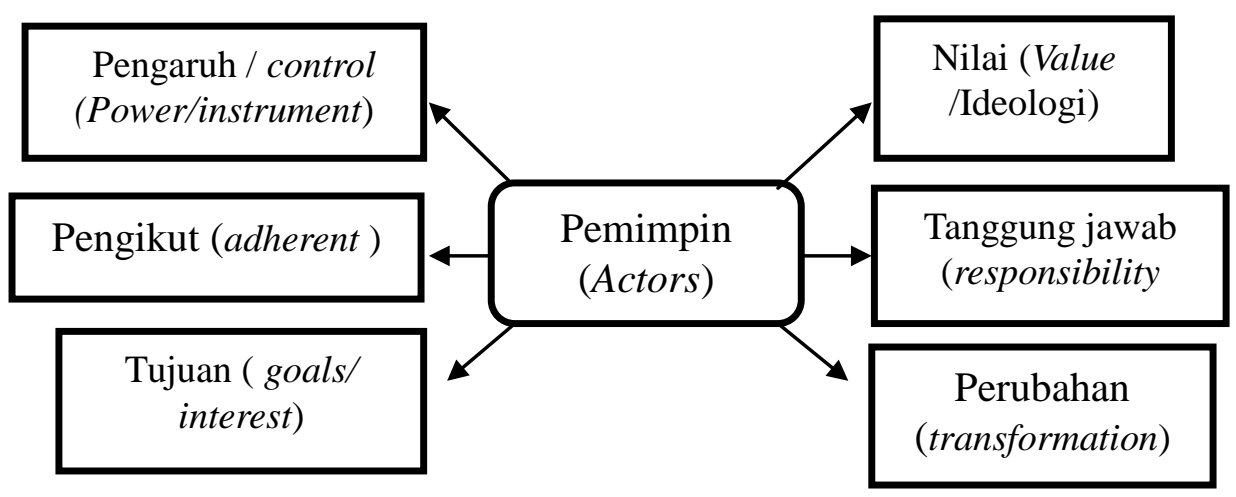

Sumber: Dikelola Pribadi dari berbagai sumber

Dari skema di atas menjadi instrumen penulis dalam menganalisa dan menjawab pertanyaan yang telah di sampaikan sebelumnya. Dengan skema tersebut akan di lihat oleh penulis dalam proses penciptaan budaya Islam dalam memupuk ukhuwah Islamiah di Makassar oleh Walikota Makassar sebagai leader di daerah tersebut. 


\section{METODE NENELITIAN}

Metode yang di gunakan dalam penulisan paper ini adalah dengan tipe penulisan deskriptif analisis, dengan teknik analisis data kualitatif. Kemudian penulis mengambil sumber data dari data sekunder atau library research atau data-data diambil dari berbagai literatur seperti buku-buku, jurnal, internet. Selain itu, penulis menggunakan data primer dengan metode wawancara kepada dosen Antropologi FISIP UNHAS dan Staf Ahli Pemkot Makassar merangkap Dosen HI FSIP UNHAS. Paper ini merupakan hasil pemikiran penulis yang dikombinasikan dengan sejumlah penelitian sebelumnya yang elaborasi dengan memasukan teori-teori sebagai instrument analisa untuk menghasilkan gagasan rasional agar bisa menjadi rujukan akademis dan praktis dalam praktek kepemimpinan di Indonesia.

\section{HASIL DAN PEMBAHASAN}

\section{Islam dan Politik di Era Otonomi Daerah}

Islam sebagai sebuah ajaran spiritual, tutunan moral, tuntuan hukum ,sosial dan budaya harus menjadi bagian dalam prospek perumusan kebijakan yang ada di Indonesia. Hal ini dimungkinkan oleh pemeluk Islam di Indonesia sekitar 80 persen. Krisis kepemimpinan dalam Islam menjadi momok menakutkan apabila tidak ada sosok figur yang ingin memulai memasukan nilai-nilai Islami dalam setiap kebijakannya terutama dalam konteks daerah. Dengan bergesernya pola dan tatacara sistem kelola pemerintah di Indonesia dari sentralistik menjadi desentralistik menunjukan sebuah perubahan besar di era reformasi. Tata kelola yang di pakai saat ini dengan sistem otonomi daerah memberikan hak sebesar-besarnya kepada daerah untuk melihat segala potensi yang dimilikinya. Sistem ini menganjurkan agar setiap pemimpin didaerah sadar betul sebagai pemimpin akan kebutuhan dan keinginan masyarakat yang dipimpinnya. Hal ini , pemerintah merumuskan Undang-undang Nomor 32 Tahun 2004 tentang Pemerintahan Daerah yang kemudian direvisi menjadi Undang-undang Nomor 12 Tahun 2008 yang kemudian direvisi lagi menjadi Undang-undang Nomor 23 Tahun 2014. Munculnya aturan tersebut memberikan wewenang kepada sejumlah daerah secara semi-otonom dalam rangka mendorong pembangunan di daerah. Oleh karena itu, melalui otonomi daerah kemandirian dalam menjalankan pembangunan sesuai dengan kapasitas dan kebutuhan daerah diharapkan dapat dilakukan dengan lebih efektif dan efisien (Fathun:2016).

Dengan legalisasi Undang-undang kepala daerah harus menyadari betul bahwa tugas pemerintah daerah buan hanya mengurusi perkembangan ekonomi di daerah berhubungan dengan investasi tetapi lebih jauh juga terkait dengan peran pemerintah daerah untuk mengurusi moralitas dan spiritual warga yang dipimpinya. Sebab, secara teoritikal apabila ahlak dan moralitas warga dari suatu daerah bagus cenderung aka nada konektivitas 
antara warga, pemerintah daerah, lembaga keagaaman dll. Tolak ukurnya adalah upaya pemerintah dalam merespon setiap kebutuhan spiritual warganya. Sebab dengan nilai spiritual cenderung bisa menyatukan visi dan ukhuwah terutama dalam konteks budaya Islam.

Menurut Rasyid (1997:100), "paradigma pemerintahan harus didasarkan pada asumsi bahwa pemerintahan dalam jangkauan masyarakat menitik beratkan pada bentuk pelayanan yang diberikan menjadi lebih cepat, hemat, murah, responsif, akomodatif, inovatif serta produktif. Diperlukan payung hukum sebagai legalitas pemekaran daerah yang diberi tugas untuk mengelola daerah otonom. Kebijakan desentralisasi tersebut tersebut sesuai dengan Pasal 1 ayat 6 Undang-Undang Republik Indonesia Nomor 23 Tahun 2014 mengenai Pemerintahan Daerah, otonomi daerah diartikan sebagai hak, wewenang, dan kewajiban daerah otonom untuk mengatur dan mengurus sendiri urusan pemerintahan dan kepentingan masyarakat setempat sesuai dengan peraturan perundang-undangan. dalam hal ini pemerintah daerah, yang merupakan kristalisasi aspirasi langsung rakyatnya.Tujuanya seperti tercantum dalam Pasal 5 yakni Pemerintahan Daerah untuk melindungi, melayani,memberdayakan, dan menyejahterakan masyarakat. Walaupun demikian, sesuai dengan tugasnya sesuai Undang-Undang Nomor 23 Tahun 2014 Pasal 10 Ayat 1 menerangkan bahwa pemerintah pusat memiliki kekuasaan absolut dalam bidang politik luar negeri, pertahanan, keamanan, yustisia, moneter dan fiskal nasional, serta agama. Menurut penulis kebijakan terkait tentang agama di Undang-undang tersebut bukan terkait dengan pelarangan kebijakan pemerintah terkait dengan membangun budaya agama di suatu daerah. Maksudnya membangun budaya agama terkhusus Islam dalam bentuk peribadatan dan spritualisasi. Justru menurut penulis dengan adanya UU tersebut harus menjadi alasan timbal balik untuk mengintervensi agama di daerahnya sebab bair bagaimanapun pemerintah daerah merupakan bagian dari NKRI.

Seperti yang telah di tuliskan diatas bahwa pemerintah daerah sebagai pemimpin dalam hal ini adalah Walikota Makassar memiliki tanggung jawab moralitas dan spritualitas untuk membangun kembali ukhuwah Islamiah di Makassar. Sejarah menuliskan bahwa Makassar menjadi salah satu Kota dengan tingkat keIslaman yang tinggi dan standar spiritual yang tinggi sejak zaman dulu. Namun hal ini semakin bergesernya zaman justru menjadikan sejumlah daerah di Indonesia kehilangan identitas ebagai Negara muslim. Mungkin hal ini bisa dilihat dari konsepsi skema yang telah di tuliskan di atas. Secara sederhana berkaitan dengan dengan kepemimpinan atau krisis kepemimpinan.

Di atas telah dituliskan bahwa Pemda sebagai pemilik hak politik berkuasa penuh terhadap daerah yang di pimpinnya. Daerah yang di pimpinya sudah menjadi amanah dan tanggung jawabnya sebagai leader. Perlu di jawab terlebih dahulu mengapa sampai budaya Islam dan 
kepemimpinan Islam itu bergeser atau mengalami keterpurukan, hampir tidak terlihat kecirikhasan suatu daerah di Indonesia yang bisa merespon penuh kebutuhan Islammis spiritual penduduknya. Akibatnya budaya Islam baik lokal dan nasional merosot dari fungsi seharusnya. Menurut analisis penulis ada beberapa hal terkait dengan hal ini : (1) ada diskursus makna bahwa Islam bukan terkait dengan pemerintahan atau politik, sederhanya Indonesia menuju pada budaya yang sekuler yakni ada pemisahan standar moralitas agama sebagai tuntunan dengan politik pemerintahan. Agama di anggap aktifitas pribadi sedangkan politik pemerintahan adalah aktifitas holistik. Akibatnya intervensi pemerintah terhadap agama, walaupun dalam konteks Indonesia penulis masih menyebutnya semi sekuler dimana masih terlihat intervensi pemerintah dalam berbagai aktifitas keagamaan. Namun kephobiaan terhadap pekebangan budaya Islam dalam politik dan pemerintahan di anggap sebagai radikalisasi, sebab Islam identik dengan radikalisasi, (2) krisis kepemimpinan, kondisi ini jelas terlihat realitasnya bahwa walaupun dalam konteks nasional telah ada sejumlah partai politik yang mewakili Islam secara makro namun identitasnya tidak mewadahi Islam secara mikro. Yang ada justru terbentuk sekte-sekte dengan kepentingan masing-masing. Mungkin ontologisnya satu yakni kebenaran Al Quran dan Hadist serta Ijma Ulama namun secara metodologis memang berbeda walaupun tujuanya sama. Dari perbedaan itulah menunjukan ketidak kompakan dalam membentuk Islam sebagai ideologis. Mengutip Greg Fealy bahwa partai politik yang mewadahi Islam seperti berikut : a) Formalist Islamic Parties (PPP,PBB,PKS), b) Pluralist Islamic Parties (PKB,PAN). Lebih rinci lagi: a) Pluralist Islamic Parties (PKB, PAN) , b) Moderate Formalist Islamic (PPP), c) Radical Formalist Islamic Parties (PKS, PBB).

Di tahun kompetisi politik berikutnya muncul satu paartai lagi yakni Partai IDAMAN yang didirikan oleh Rhoma Irma yang juga cenderung Radikal Formal. Namun Radikal yang dimaksudkan bukan untuk membunuh atau kekerasan tetapi terkait dengan konsistensi ideologis. Hal ini harus terjawab mengapa hal itu belum bisa di satukan, menurut penulis ada beberapa hal (1) Egoisme partai terkait dengan keinginan berkuasa dan merasa paling Islamis, (2) internal dan ekternal partai yang bisa saja menjadi "musuh dalam selimut" yang selalu mengadu domba antar partai, (3) konstituen yang masih memilih partai-partai nasionalis, (4) pendidikan politik dan Islam berupa sosialisasi dan keterkaitanya belum terlalu di gaungkan ( Diambil dari Materi Kuliah Penulis Pemikiran Politik Islam Di Indonesia:2015 : UMY).

\section{Karakter Kepemimpinan dalam Islam}

Dalam prespektif Islam sendiri sudah di atur secara jelas terkait dengan mencari pemimpin yang baik. Sebab dalam Islam menjadi pemimpin berkaitan dengan menjga wilayahnya sebagai wakil Allah di muka bumi. Hal ini tertuang dalam Q.S. Baqarah :30 bahwa manusia lahir dibumi sebagai 
khalifa, dan apabila tidak sesuai tuntunan Al Quran dan Hadist maka cenderung tidak adil dan hanya menimbulkan kerusakan. Mengutip Agus Saputera staf Humas Kemenag Propinsi Riau dalam tulisanya Petunjuk Al-Quran Dalam Memilih PEMIMPIN mengatakan menurut (Shihab:2002) bahwa ada dua hakekat memilih pemimpin dalam prespektif Islam yakni 1) menjadi pemimpin bukan hanya kontrak sosial antara pemimpin tersebut dan rakyatnya akan tetapi ada perjanjian dengan Allah seperti tertuang dalam $Q$. S. Al-Baqarah (2): 124 sebab memimpin dalam Islam adalah amanah seperti halnya ketika Ibrahim dipilih oleh Allah sebagai pemimpin manusia. Dengan memimpin maka seorang pemimpin memiliki kekuasaan dan wewenang maka dengan kekuassan itu tidak membuat kezaliman terhadap rakyatnya. 2) pemimpin sering juga disebut khadimul ummah (pelayan umat), maksudnya adalah pemimpin yang baik harus bisa memenuhi kebutuhan warganya bukan memperkaya diri sendiri atau berbuat tidak adil dll.

Lebih lanjut bahwa dalam prespektif Islam memilih pemimpin memiliki kriteria atau syarat semuanya terbaur di dalam empat karakter yang dimiliki oleh para nabi/rasul sebagai pemimpin umatnya, yakni: (1). Shidq, yaitu kebenaran dan kesungguhan dalam bersikap, berucap dan bertindak di dalam melaksanakan tugasnya. Kontrasnya adalah bohong. (2). Amanah, yaitu kepercayaan yang menjadikan dia memelihara dan menjaga sebaik-baiknya apa yang diamanahkan kepadanya, baik dari orang-orang yang dipimpinnya, terlebih lagi dari Allah swt. kontrasnya adalah khianat. (3) Fathonah, yaitu kecerdasan, cakap, dan handal yang melahirkan kemampuan menghadapi dan menanggulangi persoalan yang muncul. Kontrasnya adalah bodoh. (4). Tabligh, yaitu penyampaian secara jujur dan bertanggung jawab atas segala tindakan yang diambilnya (akuntabilitas dan transparansi). Lawannya adalah menutup-nutupi (kekurangan) dan melindungi (kesalahan).

Dalam Al-Quran juga dijumpai beberapa ayat yang berhubungan dengan sifat-sifat pokok yang harus dimiliki oleh seorang pemimpin, (1). Kesabaran dan ketabahan. "Kami jadikan mereka pemimpin ketika mereka sabar/tabah". Lihat Q. S. As-Sajdah (32): 24, 2). Mampu menunjukkan jalan kebahagiaan kepada umatnya sesuai dengan petunjuk Allah swt. Lihat Q. S. Al-Anbiya Ã $\varnothing$ (21): 73, (3). Telah membudaya pada diri mereka kebajikan. Lihat Q. S. Al-AnbiyaÃ $\varnothing$ (21): 73. Sifat-sifat pokok seorang pemimpin tersebut sejalan dengan pendapat yang dikemukakan oleh Al-Mubarak seperti dikutip Hafidhuddin (2002), yakni ada empat syarat untuk menjadi pemimpin: Pertama, memiliki aqidah yang benar (aqidah salimah). Kedua, memiliki ilmu pengetahuan dan wawasan yang luas ('ilmun wasi un). Ketiga, memiliki akhlak yang mulia (akhlaqulkarimah). Keempat, memiliki kecakapan manajerial dan administratif dalam mengatur urusan-urusan duniawi.

Disamping itu mengutip Majalah As-Sunnah Edisi 04/Tahun XII/1429H/2008M. Diterbitkan Yayasan Lajnah Istiqomah Surakarta dalam 
tulisan Ustadz Abu Ihsan al-Atsari mengatakan bahwa Nabi Muhammad bersabda Tiga doa yang tidak tertolak: Doa pemimpin yang adil, orang yang puasa hingga berbuka, dan doa orang yang dizhalimi.Lebih lanjut pemimpin yang baik adalah pemimpin yang bisa menjadi imam bagi rakyat yang dimpinpinya. Dalam Hadist Nabi bahwa imam atau pemimpin yang baik merupakan salah satu orang yang mendapatkan naungan Allah di akhirat.Bahkan lebih ekstrim lagi bahwa Qeis bin Sa'ad berkata,"Sehari bagi imam yang adil, lebih baik daripada ibadah seseorang di rumahnya selama enam puluh tahun." Oleh sebab itu, memilih pemimpin yang baik dalam perdebatan hukum Islam memang ada perselisihan, antara wajib ain dan wajib kifayah.Dalam prespektif menurut golongan menurut golongan Najdat, salah satu sekte Khawarij, utamanya Fathiyah Ibn Amir al-hanafi, mengangkat pemimpin itu hukumnya mubah. Artinya, terserah pada kehendak umat atau rakyat mau melakukannya atau tidak. Umat atau rakyat tidak berdosa karena meninggalkannya, dan tidak pula mendapat pahala bila melakukannya. Sebab tidak satu pun argumentasi naqliyah yang memerintahkan atau melarangnya. Menurut kaum Sunni, mengangkat kepala negara itu merupakan kewajiban berdasarkan syari'at atau agama. Dari dua pendapat itu penulis lebih menyetuji bahwa memilih pemimpin harus konssiten artinya memilih pemimpin harus kompak, harus sepemahaman, satu visi dan misi dan satu tujuan. Sehingga, menurut penulis lebih menyetujui hukumnya fardu kifayah. Argumentasinya adalah keputusan kolektif akan berpengaruh terhadap proses naik atau tidaknya dalam sebuah kekuasaan, sebab kalau hanya mengandalkan individual tanpa koordinasi cenderung sulit mewadahi aspirasi. Sehingga, disinilah peran ulama sebagai koordinator. Karena ayat kuncinya ada di Q.S Annisa ayat 59 bahwa harus menjadi ulil amri karena ketaatan itu sama dengan mentaati Allah dan Rasulnya.

Menurut penulis dua masalah pokok tersebut mewakili debat innen politik dan struktur politik dalam ideologi Islam. Innen politik terkait dengan pemimpinnya dan struktur politik terkait dengan partai politik, sistem politik dan pemerintahan. Hal inilah yang coba di bangun di Makassar dalam konteks pemerintahan daerah. Dengan terpilihnya Dani Pomanto sebagai Waliota yang baru, Dani Pomanto mencoba merespon perbedaan budaya lokal Islam di Makassar. Walaupun di Makassar juga masih terbilang banyak sekte-sekte keagaaman, sebut saja Tablig, Wahda Islamiah, HTI, bahkan Syiah namun Walikota Makassar menyadari betul akan metodologi setiap sekte itu memiliki tujuan yang sama sehingga harus direspon dalam bentuk kebijakan politik yang merangkul semua kalaangan dengan satu nama Islam.

\section{Islam dan Politik Di Makassar}

Walikota Makassar menyadari betul bahwa Islam dan politik tidak bisa dipisahkan. Asumsi ini bisa saja di ilhami oleh pernyataan (Bahtiar Efendy: 2001) bahwa Islam tidak saja dipahami sebagai sebuah nilai-nilai 
yang diperjuangkan di arena politik. Islam juga berfungsi sebagai instrumen untuk memperjuangkan dan mempertahankan kekuasaan. Dalam buku yang sama Efendi menyatakan bahwa Islam tidak kompetibel dengan demokrasi, justru menurut penulis Islam itu sangat demokratis. Ada dua Kemungkinan itu:1. Islam harus menjadi landasan dalam bernegaran (formalis siasah), 2. Islam dalam konteks esensi. Pola pikir kedua ini bisa berjalan dengan demokrasi modern. (keadilan, persamaan, partisipasi, kejujuran, integritas dan kapabilitas). Dalam arti inilah demokrasi keIslaman atau berdasarkan value sebagai power politict.

Walaupun praktenya di Makassar belum pure menggunakan sistem Islam sebagai konstitusi seperti kemungkinan pertama akan tetapi pola Islam dan politik di Makassar mencoba menggeser nilai Islam bukan hanya ada pada kemungkinan kedua diatas tetapi tetapi memasukan ke kemungkinan pertama. Dalam arti ada intervensi pemerintah terhadap pembentukan budaya Islam di Makassar. Hal ini terbukti seperti yang di beritakan oleh Republika.co.id pada Senin, 09 Mei 2016, 22 :17 WIB menunjukan pola kepempinan Danny Pomanto, untuk mencanangkan shalat subuh berjamaah yang sengaja sengaja dirancang pada kegiatan Makassar City Expo 2016. Dalam kegiatan tersebut Sejumlah pimpinan unit kerja di lingkup kota Makassar, termasuk Wakil Wali Kota Makassar Syamsu Rizal dan juga Sekda Kota Ibrahim Saleh Makassar terlihat hadir menunaikan ibadah sholat subuh berjamaah.Menuurut Dani Pomanto"Shalat subuh berjamaah ini kita gelorakan sebagai gerakan moral di Makassar yang menjadi pemersatu dan kekompakan kita dalam membangun Makassar dua kali tambah baik. Inilah syiar yang bukan hanya berorientasi dunia, tapi akhirat sebagai tujuan yang kekal.

Lebih lanjut Menurut Danny, salat subuh bukan hanya ritual agama yang wajib dilakukan umat muslim. Esensi salat jumat berjemaah juga menjadi momentum meningkatkan tali silaturahim antar sesama umat muslim, khususnya lingkup Pemkot Makassar. Danny mengatakan program salat subuh berjemaah yang sudah menjadi program tetap Pemkot Makassar ini diharapkan dapat diikuti seluruh umat muslim di Makassar, termasuk kalangan pelajar dan mahasiswa muslim. Mengutip pula Hidayatullah.com bahwa ada ribuan orang melakukan ibadah Shalat Subuh berjamaah di anjungan Pantai Losari Makassar. Mereka datang guna mengikuti Gerakan Makassar Shalat Subuh Bersama, di Anjungan Pantai Losari Makassar pada minggu31/07/2016.Para jamaah berasal dari unsur Satuan Kerja Perangkat Daerah (SKPD), Perusahaan Daerah (Perusda), pegawai negeri sipil (PNS) Pemkot Makassar dan para pelajar. Lebih tegas Walikota Makassar mengatakan " shalat adalah tiang agama dan berjamaah adalah perahu kebersamaan maka Insya Allah akan semakin merekatkan pemerintah bersama rakyatnya menuju Makassar Dua Kali Tambah Baik seperti yang kita cita-citakan bersama. Selain itu, Danny mengungkapkan bahwa shalat subuh merupakan salah satu ritual yang sangat berat bagi sejumlah kamum 
muslimin, dia berharap dengan menjadikan program shalat subuh secara berjemaah di Pantai Losari akan lebih meningkatkan solidaritas dan silaturahmi di antara warga Makassar.

Realitas di atas, membuktikan dan menjadi contoh yang baik konsistensi pemerintah Kota Makassar dalam mengintervensi penerapan nilai-nilai spritual sebagai bagian dari pembentukan moralitas di Makassar. Tentu menjadi pertanyaan mengapa sampai Walikota Makassar memilih gerakan shalat subuh sebagai nilai moralitas dalam membangun silahturahmi. Tentunya hal ini tidak terlepas dari (1) faedah dari sholat subuh tersebut misalnya pahala sholat subuh sama dengan sholat tahajud semalam suntuk, selain itu dalam surah Al Fajr Allah juga bersumpah demi Fajar atau subuh. Kemudian dalam surah Al isra ayat ke 78 yang menyatakan bahwa sholat subuh itu di saksikan oleh para malaikat, bahwkan sholat kabilah subuh 2 rakaat saja faedahnya melebihi dunia dan seisisnya, (2) sholat subuh terkadang menjadi beban yang berat apabila dilaksanakan menjadi logika terbalik Walikota Makassar bahwa dengan melaksanakan sesuatu yang di anggap berat dan apabila bisa dikontrol dengan baik maka akan menjadi budaya yang baik, (3) subuh memiliki histori yang sangat kuat di dalam Islam ketika membentuk ukhuwah, misalnya ketika Salahudin Al ayubi menyerang Raja Ricard yakni sehabis sholat subuh. Itu artinya ada kekhawatiran dari musuh-musuh Islam bahwa subuh adalah waktu yang tepat dalam membangun ukhuwah. Karena, apabila jamaah sholat subuh melebihi sholat jumat maka ada tekanan psikologis bagi musu-h musuh Islam ketika meraka masih tertidur lelap kaum muslim sudah di budayakan dengan bangun subuh untuk menyambut pagi hari. Bahkan ada asumsi " ancaman terberat dan ancaman bagi kaum yahudi dari Islam adalah ketika jamaah subuh lebih banyak dari sholat jumat”.

Disini uniknya justru dari kecenderungan beratnya bagi sejumlah orang untuk melaksanakan sholat subuh secara berjamaah justru dimanfaatkan dengan baik dan menggunakan logika terbalik oleh Walikota Makassar untuk membangun silaturahim. Artinya, beban bagi sejumlah orang apabila di kontrol secara baik dengan pendekatan persuasif maka akan menjadi kekuatan yang luar biasa untuk membangun ukhuwah. Disinilah penulis memahami Walikota Makassar memahami betul faedah shalat subuh sehingga dengan menjadi bagian dari program pemerintah, menjadi bukti keterhubungan antara nilai subtantif Islam dan politik. Sehingga, penulis mengatakan Walikota Makasar menerapkan strategi pendekatan shalat subuh sebagai bagian membanguan ukhuwah. Indikatornya seperti yang telah dituliskan dan dinyatakan oleh Walikota Makassar bahwa tujuan program ini adalah mebangun silaturahim, menyatukan masyrakat dengan dengan pemerintah serta swasta. Sehingga, dari analisis skema yang telah di tuliskan di atas sudah jelas power politiknya adalah shalat subuh, dengan karakter kepemipinan religius Danniy Pomanto menjadikan sholat subuh menjadi tujuan bersama serta sudah jelas akan mentranfromasikan nila-nilaai 
keIslaman dalam setiap kebijakan pemerintah Kota Makassar. Ada perubahan etika masyarakat ketika kontrol politik terhadap fenomena sosial keagamaan. Dalam konteks ini Danny mebuktikan secara faktual psikologi politik yang dimilikinya dengan berlandaskankan nilai -nilai agama. Sehingga, Danny melalui respon kebijakan bisa membentuk ukhuwah dan cenderung akan mendatangkan lebih banyak orang lagi dibanding tanggal 31/07/2016 yang di hadiriri ribuan orang. Faktanya bahwa ternyta begitu mudah membentuk ukhuwah apabila pemerintah yang merespon kebijakan memami ssosio kultural didaerahnya yang seharusnya menjadi power politik yang dominan.

Lebih jelas dalam analisis psikologi kepemimpinan ada tiga variabel kunci menjelaskan hal ini (Yuki:2005) menyangkut Krakteristik Pemimpin (Leader) menyangkut seperti : Ciri (motivasi, kepribadian, nilai) Keyakinan dan optimism Keterampilan dan keahlian Perilaku Integritas dan etika Taktik pengaruh Sifat pemimpin, 2) Karakteristik Pengikut (Society) menyangkut :Ciri (keb., nilai, konsep pribadi) Keyakinan dan optimisme Keterampilan dan keahlian Sifat dari pengikut Kepercayaan pada pemimpin Komitmen dan upaya tugas Kepuasan thd pemimpin \& pekerjaan serta 3) Krakteristik Situasi (Situation ) Jenis unit organisasi Besarnya unit organisasi, Posisi kekuasaan dan wewenang, Struktur dan kompleksitas tugas, Kesaling tergantungan tugas, Ketidak pastian lingkungan, Ketergantungan eksternal. Dari kolaborasi tiga variabel tersebut Walikota Makassar memahami betul kondisi dia sebagai pemimpin, msyarakat yang dipimpinya dan instrument pendekatanya yakni dengan shalat subuh. Dengan pendekatan yang sama, tujuan yang sama, motivasi yang sama dan dalam situasi nilai yang dipahami bersama yakni shlata subuh secara berjamaah menjadi keutamaan dankecirikhasan dari power politik Danny Pomanto.

Dengan tipe kepemimpinan Walikota Makassar adalah upaya mengembangkan satu sama lain tingkat moralitas dan motivasi yang tinggi, (Bernard M. Bass:1999) menyebutnya sebsgai pemimpin transformatif. Transformational adalah "a person who displays or creates charismatic leadership, inspirational leadership, intelectual stimulation, and a feeling that each individual follorer counts". Dapat diartikan bahwa seorang pemimpin tranformasional adalah seseorang yang menciptakan kepemimpinan kharismatik, kepemimpinan yang penuh inspirasi, stimulasi intelektual dan perasaan bahwa semua bawahan harus diperhitungkan. Lebih lanjut Pidekso dan Harsiwi, 2001) menyatakan bahwa ada beberapa ciri dari karakter kepemimpinajn seperti ini yaitu: 1) Idealized Influence Charisma, yaitu memberi wawasan serta kesadaran akan misi, membangkitkan kebanggaan, serta menumbuhkan sikap hormat dan kepercayaan pada para bawahannya, 2) Inspirational Motivation, yaitu menumbuhkan ekspektasi yang tinggi melalui pemanfaatan simbol-simbol untuk memfokuskan usaha dan mengkomunikasikan tujuan-tujuan penting dengan cara yang sederhana. 3) Intellectual Stimulation, yaitu meningkatkan 
intelegensia, rasionalitas, dan pemecahan masalah secara seksama. 4) Individualized Consideration, yaitu memberikan perhatian, membina, membimbing, dan melatih setiap orang secara khusus dan pribadi.

Skema 2 : Model Kepmimpinan Transformatif

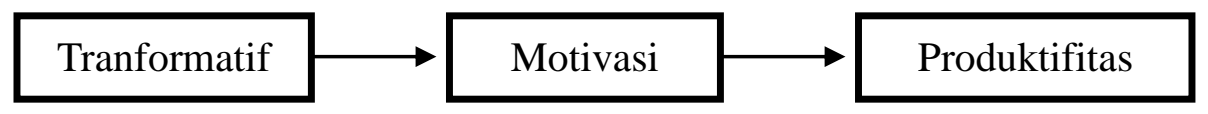

Sumber: Ratnaningsih:2009

Dengan demikian, bukti di atas menunjukan bahwa Danni Pomanto bisa dikatakan sebagai salah satu pemimpin yang religius. Danni Pomanto menyadari betul instrumen yang bisa membangun moralitas kebersamaan dalam penyatuan antara politik dalam bentuk kebijakan dan Islam sebagai cita-cita. Ada kombinasi yang linear antara politik dan Islam. Hal ini menjadi salah satu bukti bahwa tidak ada jurang antara politik dan Islam, justru Islam harus dipahami sebagai landasan holistik bukan sekedar spritual dan ritual. Islam telah hadir dengan sempurna dalam mebantuk budaya, tata prilaku, moralitas hukum, sosial, ekonomi dan politik. Dan menurut penulis kebijakan yang telah di perankan oleh Walikota Makassar harus dijadikan contoh bagi sejumlah kepala daerah di Indonesia. Tujuan akhirnya adalah menciptakan ukhuwah.

Keciri khasan Walikota Makassar yang religius menunjukan seberapa baik pemimpin tersebut menjadi contoh dalam memhami syariat sebagai siasah dalam Islam. Menjadikan shalat subuh sebagai perekat di Makassar menunjukan karakter pemimpin yang mampu menjadi penyatu ukhuwah di atara penduduk di Makassar. Artinya dengan melihat faedah shalat subuh menjadi bukti kereligiusan Danny Pomanto sebagai salah satu figur religius di Indonesia di masa depan.

\section{PENUTUP}

Setelah memalui proses analisis di atas sebagai penutup penulis menyimpulkan bahwa intervensi politik terhadap nila-nilai spiritual dalam Islam menjadi kebijakan strategis pemerintah Kota Makassar untuk menciptakan Makassar dengan standar moralitas Islam. Dengan istrumen saholat subuh bersamaan segala faedahnya Walikota Makassar memahami benar bahwa dengan sholat subuh berjamaah dan mejadi program pemerintah bisa menjadi salah satu cara pemerintah memupuk rasa silaturahim dan ukhuwah Islamiah. Artinya kebijakan tersebut lahir dari pemahaman pemimpin yang religious yang mampu menyatukan visi keIslaman dengan wewenang politik yang dimilikinya. Sehingga, tidak salah apabila penulis menyebutnya sebagai pemimpin yang tranformatif yang bisa mewadahi nila0nilai religious dalam format dan implemntasi kebijakan. Oleh sebab itu, penting bagi sejumlah pemimpin didaerah untuk melihat realitas ini sebagai langkah maju untuk memumpuk ukhuwah Islamiah. Sebab, dengan control politik yang baik dengan nilai religious yang dipahami bersama bisa menjadi kekuatan strategis 


\section{Islãmadîna \\ JURNAL PEMIKIRAN ISLAM}

menjadikan Islam ukhuwah dan bersatu tanpa adanya sekte metodlogis. Artinya kesadaran metodologis sebaiaknya jangan menjadi penghalang untuk membentuk ukhuwah, sebab tujuan bersama menjadi pedoman dan cita-cita bersama. Perdebatan metodologis terkait tentang cara memahami realitas hanya menjadi masalah yang justru memicu perpecahan di antara sesame muslim. Oleh sebab itu, yang paling penting saat ini adalah melahirkan pemimpin, yang religious yangamanah, adil, jujur, integritas, paham agama sehingga bisa menjadi pemimpin seperti yang di syaritakan dalam Annisa ayat ke 59.

\section{DAFTAR PUSTAKA}

Bass. M,B. 1990. Bass and Stogdill's Handbook of Leadership. Nwe York: Free Press.

Ishomuddin.2011. Pengantar Sains Politik Islam. Malang: Bangumedia Publishing,

Muhamad Fathun, Laode. 2016. Traansformasi Isu-Isu Hubungan Internasional Pasca Perang Dingin.Yogyakarta: Magister Hubungan Internasional, Universitas Muhammadiyah Yogyakarta.

Rasyid, M. R.1997. Kajian Awal Birokrasi Pemerintahan dan Politik Orde Baru. Jakarta: Yarsip Watampone.

Thoha, Miftah, 2010.Perilaku Organisasi Konsep Dasar dan Aplikasinya, Jakarta: PT Raja Grafindo Persada.

2010. Kepemimpinan Dalam Manajemen, Jakarta : Rajawali Pers.

Tibi , Basan.2000. Ancaman Fundamentalisme "Rajutan Islam Politik dan Kekacauan Dunia Baru. Yogyakarta: Tiana Wacana Yogyakarta.

Surwandono dan Sidiq Ahmad.2011. Resolusi Konflik Dunia Islam. Yogyakarta: Graha Ilmu.

Yulk Gary. 2000. Kepemimpinan Dalam Organisasi.Cetakan Pertama, Jakarta : PT.Indeks.

Wahjosumidjo. 2005. Kepemimpinan Kepala Sekolah. Jakarta: Rajawali Grafindo Persada.

Adiong , Nassef.2013. Journal of Islamic State Practice In International law, Volume 9 No.1. Summer Electronic Publication.org. Ltd.

Muhamad Fathun, Laode. 2015. Isis Dalam Diskursus Pembentukan Negara Bangsa. Yogyakarta. ThaqafiyyaT Vol. 16, No. 2, Desember: UIN Sunan Kalijaga Yogyakarta.

2016. Paradiplomacy Menuju Kota Dunia Studi Kasus

Pemerintah Kota Makassar, Jurnal Indonesian Prespectives. Semarang Jawa Tengah:Universitas Diponegoro.

Majalah As-Sunnah Edisi 04/Tahun XII/1429H/2008M. 